\title{
Physico-Mechanical Characterization of Clay and Laterite Bricks Stabilized or Not with Cement
}

\author{
Mathioro Fall1', Déthié Sarr², Elhadji Malick Cissé1, Daouda Konaté1 \\ ${ }^{1}$ Department of Civil Engineering, UFR SI, University of Thies, Thies, Senegal \\ ${ }^{2}$ Department of Geotechnic, UFR SI, University of Thies, Thies, Senegal \\ Email: mathioro.fall@univ-thies.sn
}

How to cite this paper: Fall, M., Sarr, D., Cissé, E.M. and Konaté, D. (2021) Physico-Mechanical Characterization of Clay and Laterite Bricks Stabilized or Not with Cement. Open Journal of Civil Engineering, 11, 60-69.

https://doi.org/10.4236/ojce.2021.111004

Received: January 13, 2021

Accepted: February 23, 2021

Published: February 26, 2021

Copyright $\odot 2021$ by author(s) and Scientific Research Publishing Inc. This work is licensed under the Creative Commons Attribution International License (CC BY 4.0).

http://creativecommons.org/licenses/by/4.0/

\begin{abstract}
This study focuses on the valuation and optimization of local materials to meet the challenge of sustainable development. Faced with climate change and the preservation of the environment, research into eco-materials is necessary to reduce the energy bill while ensuring comfort and safety. The objective is to make a comparative characterization of the physico-mechanical properties of compressed earth bricks made from local materials: clay, laterite and sand. These are, on the one hand, bricks made from clay and laterite, reinforced with a percentage of sand varying between $20 \%$ and $30 \%$ in steps of $5 \%$., were made. On the other hand, these same mixtures stabilized with 5\% cement (CEM II-32.5) are also used to produce bricks. A characterization of the raw materials was made before studying the physico-mechanical properties of the bricks themselves. This involved evaluating the water absorbency and compressive strength of stabilized and unstabilized bricks. The results show that the absorptivity of stabilized clay bricks is acceptable up to $25 \%$ sand because it is less than the $15 \%$ maximum value set by Cameroonian standard NC-104: 2002-06. However, that of stabilized laterite bricks is higher than the maximum value set by the standard. The compressive strengths, for clay bricks stabilized with 5\% cement and for laterite bricks with $0 \%$ sand added, are all greater than $2 \mathrm{MPa}$ and therefore are acceptable. In addition, clay bricks with $20 \%$ sand and stabilized with $5 \%$ cement are recommended because they have the most optimal physico-mechanical properties.
\end{abstract}

\section{Keywords}

Brick, Laterite, Clay, Absorptivity, Compressive Strength 


\section{Introduction}

The valuation of local materials in the construction of homes and public buildings is a necessity from a sustainable development perspective. Reducing the use of concrete for low-income countries has both environmental and economic benefits.

This work focuses on a characterization of the properties of local materials: clay and laterite for application in the building sector. The objective is to determine the physico-mechanical characteristics of clay and laterite bricks stabilized with sand and cement. This study will allow, depending on the areas and the availability of one of the materials, to get an idea of their quality and properties.

A characterization of the raw materials: laterite, clay and sand will be made from testing to assess the quality of the base materials. These tests will determine the grain size, the sand equivalent and the specific weight of the laterite and sand, the plasticity index. In addition, water absorbency and compressive strength will be determined for bricks made from mixtures (clay plus sand and laterite plus sand) stabilized with cement.

\section{Methodoly}

This work is always part of the search for a formulation and optimization of local materials. Figure 1 shows the collection sand, laterite and clay samples.

The first step is to characterize the raw materials consisting of sand, laterite and clay from the identification tests. Thus, the following parameters will be studied: specific weight, particle size, sand equivalent, Atterberg limits and methylene blue.

The specific gravity gives an idea of the density of the soil and guides on the best method to use for an accurate classification of soils.

The granulometry makes it possible to determine the size and the respective weight percentages of the different families of grains constituting the sample.

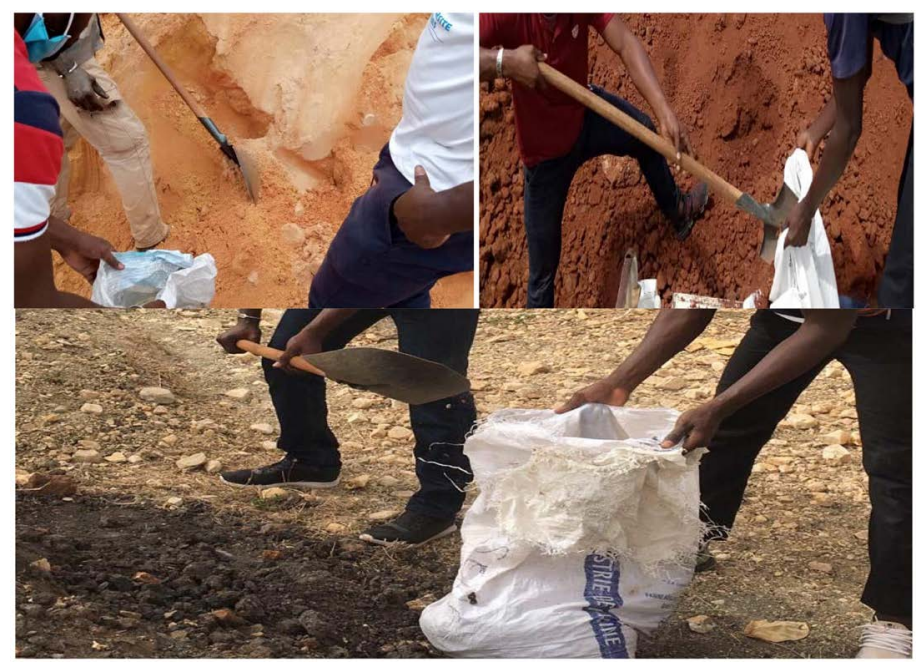

Figure 1. Collecting samples of sand (left), laterite (right) and clay (bottom). 
The sand equivalent tells us about the cleanliness of the sample, especially the presence of fine particles. The cleanliness of the aggregate is a very important parameter in the formulation of bricks.

Concerning the Atterberg limits, they are carried out on the particle size fraction of the soil with a diameter of less than $0.4 \mathrm{~mm}$. These limits are a good way to characterize the influence of water in the soil on its mechanical behavior [1]. This test makes it possible to evaluate the plasticity index (Ip) from the liquidity limit (Wl) and the plasticity limit (Wp). The plasticity index measures the range of water contents within which the material is able to be shaped. The liquidity limit corresponds to the water content characterizing the transition between the plastic state and the liquid state. The plastic limit corresponds to the water content characterizing the transition between the solid state and a plastic state. This is the limit below which it is no longer possible to make $3 \mathrm{~mm}$ diameter sausages.

Soil methylene blue (VBS) value measures the adsorption capacity of soil or rock material. It constitutes one of the identification parameters of the classification of soils described in standard NF P 11-300 [2].

The principle of the test is to determine the quantity of methylene blue necessary to cover with a supposed mono-molecular layer the internal and external surfaces of clay particles, organic matter and hydroxides dispersed in water. The principle of the test is to determine the quantity of methylene blue necessary to cover with a supposed mono-molecular layer the internal and external surfaces of clay particles, organic matter and hydroxides dispersed in water. The dosage in methylene blue solution is shown on the left of Figure 2. It is carried out by successively adding quantities of solution and monitoring the adsorption as and when. A drop of suspension is then taken and deposited on a filter (the right part of Figure 2). The test consists of determining the maximum absorption obtained when the spot is surrounded by a persistent light blue halo. When the presence of blue is confirmed, the soil blue value or VBS is given by the ratio of the mass of blue to the dry mass of soil used.

After the characterization of the raw materials, bricks with dimensions of 15 $\mathrm{cm} \times 12 \mathrm{~cm} \times 5 \mathrm{~cm}$, based on clay and based on laterite were made with sand percentages varying between $20 \%$ and $30 \%$. In addition, bricks were produced with the same mixtures stabilized with $5 \%$ cement. Figure 3 below shows clay bricks and laterite bricks.
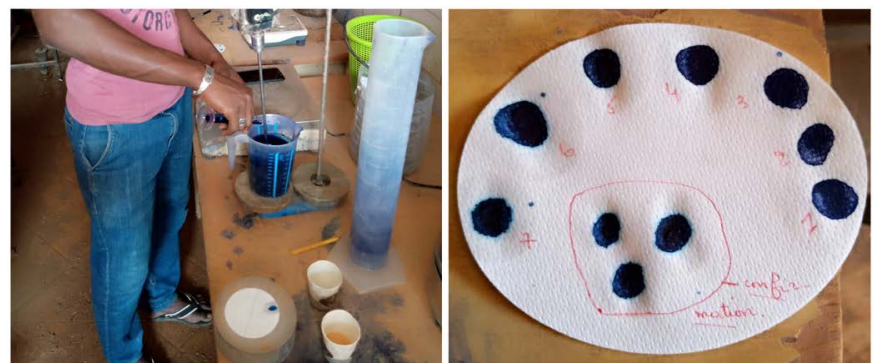

Figure 2. Methylene blue test. 


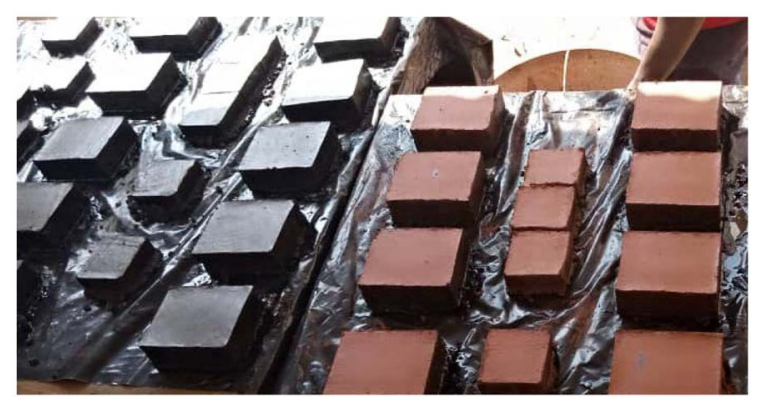

Figure 3. Clay bricks (left) and laterite bricks (right).

For mechanical strength, crushing tests were carried out on the bricks. A 2000 $\mathrm{kN}$ capacity compression machine was used to determine the 28-day compressive strength of the samples. The compressive strength is obtained by the ratio of the maximum force on the section of the brick.

The absorption test makes it possible to evaluate the quantity of water retained by the porosity of the aggregates in order to take it into account for the effective water dosage during the formulation of concrete. The tests were carried out on bricks stabilized with cement, according to the guidelines of standard NBN B 15-215 [3]. The samples are immersed in a water tank at $20^{\circ} \mathrm{C} \pm 2{ }^{\circ} \mathrm{C}$ for 48 hours and were dried for 24 hours in an oven.

The water absorption by immersion (Abs) is expressed as a percentage of the dry mass and is calculated by the following relationship [3].

\section{Results and Discussions}

\subsection{Granulometry}

The results of the tests made it possible to draw the following grain size curves. The uniformity and curvature coefficients are obtained from the exploitation of the curves. These coefficients are shown in Table 1.

The coefficient of curvature $(\mathrm{Cc})$ and the coefficient of uniformity $(\mathrm{Cu})$ show that the sand has a spread and well graded particle size with respect to laterite and clay, they have a spread and poorly graded particle size [4].

\subsection{Atterberg Limits}

The results of the Atterberg limits tests are reported in Table 2.

The results give plasticity indices (Ip) equal to $32 \%$ and $16.4 \%$ respectively for clay and for laterite. These values prove that the clay and laterite used have a plastic behavior [5] [6].

\subsection{Equivalent Sand}

The results of the sand equivalent (ES) tests on that of Thiénaba (Senegal) are shown in Table 3.

The equivalents of piston and of sight sand are equal to $28 \%$ and $86 \%$, respectively. These values show that the sand is clayey [1] [3]. 
Table 1. Coefficients of curvature $(\mathrm{Cc})$ and uniformity $(\mathrm{Cu})$ of clay, laterite and sand.

\begin{tabular}{ccc}
\hline Materials & $\mathrm{Cu}$ & $\mathrm{Cc}$ \\
\hline Clay & 3.6 & 0.449 \\
Laterite & 96.42 & 0.021 \\
Sand & 2.6 & 1.24 \\
\hline
\end{tabular}

Table 2. Limits of liquidity (Wl) and plasticity (Wp), plasticity (Ip) and consistency (Ic) indices of clay and laterite.

\begin{tabular}{ccccc}
\hline Materials & WL $(\%)$ & Wp (\%) & Ip (\%) & Ic \\
\hline Clay & 55.2 & 23.2 & 32 & 1.66 \\
Laterite & 32 & 15.6 & 16.4 & 1.82 \\
\hline
\end{tabular}

Table 3. Equivalent of piston and of sight sand.

\begin{tabular}{ccc}
\hline Material & Sand equivalent (ES) of piston & Sand equivalent (ES) of sight \\
\hline Sand & 28 & 86 \\
\hline
\end{tabular}

\subsection{Methylene Blue}

The results of the methylene blue test are summarized in Table 4.

For clay, the methylene blue value of the soil is $6.14 \%$. This value shows that the clay used belongs to the family of clay soils whose blue values are between 6 and 8 .

For laterite, the value of methylene blue, equal to 1.84 , is in the range [1.5 2.5], characterizing sandy clay soils with low plasticity [7].

\subsection{Specific Gravity}

The specific gravity ( $\gamma$ s) of the laterite, sand and clay are recorded in the Table 5.

Table 5 shows that the specific gravity of clay, laterite and sand are equal to $2.43 \mathrm{~g} / \mathrm{cm}^{3}, 2.77 \mathrm{~g} / \mathrm{cm}^{3}$ and $2.68 \mathrm{~g} / \mathrm{cm}^{3}$, respectively. Indeed, a material consists of light particles if the specific weight is less than $2.6 \mathrm{~g} / \mathrm{cm}^{3}$ and if the latter is greater than $2.6 \mathrm{~g} / \mathrm{cm}^{3}$, the material is composed of heavy particles [3]. Based on this observation, clay is made up of light particles while sand and laterite are made of heavy particles.

\subsection{Mechanical Resistance}

Compression tests were carried out on the laterite and clay bricks. The results are reported in Table 6.

The resistance values were used to draw the curves in Figure 4.

The resistance values vary between 0.5 to $1.24 \mathrm{MPa}$ and 0.90 to $1.62 \mathrm{MPa}$ respectively for clay and for laterite. The maximum strengths of 1.24 and $1.62 \mathrm{MPa}$ respectively for clay and for laterite, are obtained at $20 \%$ sand. These results also show that the compressive strength of clay is greater than that of laterite. This is due to the good cohesion of the clay made up of fine and light particles. In addi- 
tion, clay is a natural binder and helps reduce the porosity of bricks by occupying the space between grains of sand [8].

However, the compressive strength of all bricks is less than $2 \mathrm{MPa}$ for all formulations. To improve these strengths, all the formulations were stabilized at $5 \%$ cement (CEM II-32.5).

The results of the compression tests on bricks stabilized with $5 \%$ cement are given in Table 7.

These results are shown in Figure 5.

Table 4. Methylene blue values.

\begin{tabular}{cl}
\hline Materials & VBS \\
\hline Clay & 6.14 \\
Laterite & 1.84 \\
\hline
\end{tabular}

Table 5. Specific gravity.

\begin{tabular}{cc}
\hline Materials & $\gamma \mathrm{s}$ \\
\hline Clay & 2.43 \\
Laterite & 2.77 \\
Sand & 2.68 \\
\hline
\end{tabular}

Table 6. Compressive strength of clay and laterite bricks as a function of the percentage of sand.

\begin{tabular}{ccccc}
\hline Percentage of sand & $0 \%$ & $20 \%$ & $25 \%$ & $30 \%$ \\
\hline Clay & 1.24 & 1.38 & 1.28 & 0.5 \\
Laterite & 1.62 & 1.44 & 0.62 & 0.90 \\
\hline
\end{tabular}

Table 7. Compressive strength of clay and laterite bricks as a function of the percentage of sand and stabilized with $5 \%$ of cement.

\begin{tabular}{ccccc}
\hline Percentage of sand & $0 \%$ & $20 \%$ & $25 \%$ & $30 \%$ \\
\hline Clay $+5 \%$ cement & 4.17 & 4.94 & 3.65 & 2.54 \\
Laterite $+5 \%$ cement & 2.47 & 1.97 & 1.32 & 0.74 \\
\hline
\end{tabular}

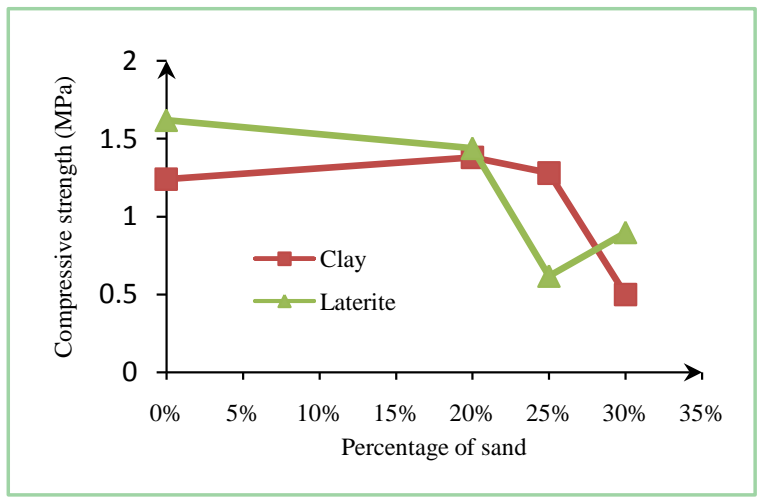

Figure 4. Compressive strengths of clay and laterite bricks. 


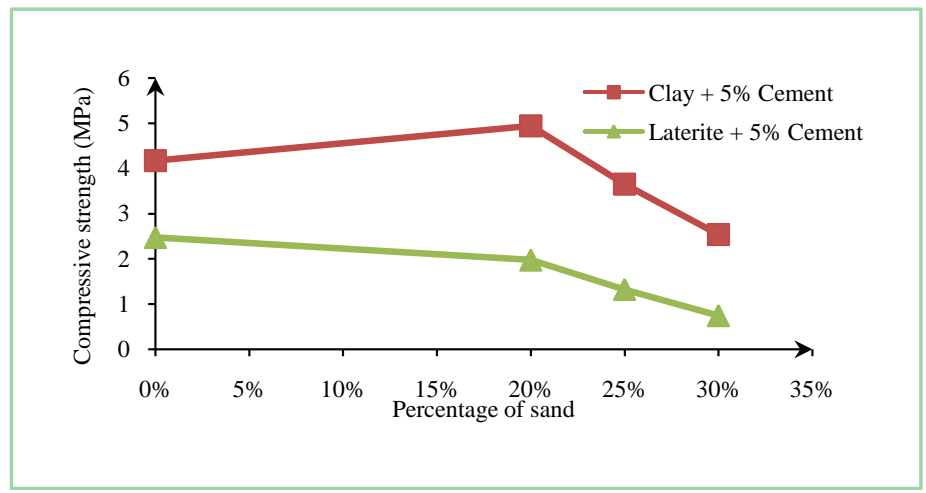

Figure 5. Compressive strengths of bricks, stabilized with 5\% cement, clay and laterite.

After stabilization, the compressive strength varies between 2.54 to $4.17 \mathrm{MPa}$ and 0.74 to $2.47 \mathrm{MPa}$ for clay and laterite respectively. For clay we see that the maximum strength of $4.94 \mathrm{MPa}$ is noted at $20 \%$ sand while this maximum of $2.47 \mathrm{MPa}$ is noted at $0 \%$ sand for laterite. Also, in general, resistance decreases with increasing percentage of sand. The increase in the percentage of sand leads to an increase in the porosity of bricks by default of binders [8] [9] [10].

The synthesis of the results of the compression tests, on the stabilized and unstabilized bricks, is shown in Figure 6.

This figure shows that the compressive strength for all formulations is doubled. In addition, it indicates that the compressive strength of clay bricks is much higher than that of bricks produced from laterite. In addition, the maximum strengths, equal to $1.38 \mathrm{MPa}$ and 4.94 MPa respectively for unstabilized bricks and those stabilized, are obtained at $20 \%$ sand, made from clay, while for laterite, the maxima are obtained at $0 \%$ sand. This is justified by the fact that the laterite used already contained sand and the addition of the latter further weakens the lateritic bricks. [8] [10].

Thus, for bricks stabilized with $5 \%$ cement, compressive strengths are acceptable (greater than $2 \mathrm{MPa}$ ) for all clay bricks and for laterite bricks with $0 \%$ sand added [11] [12] [13].

\section{Absorptivity}

The results of absorptivity tests on laterite and clay bricks, stabilized with $5 \%$ cement, are shown in Table 8 below.

The evolution curves of the absorptivity are shown in Figure 7. This figure shows that the absorptivity varies between $3.70 \%$ to $15.45 \%$ and between $19.11 \%$ to $25.42 \%$ respectively for clay and laterite. These results show that the absorptivity of laterite bricks is greater than that of clay bricks. This is due to the greater porosity of laterite bricks compared to that of clay bricks.

Likewise, the absorptivity of clay bricks increases with the percentage of sand added, unlike laterite bricks which give absorptivities which gradually decrease with the fraction of sand. 


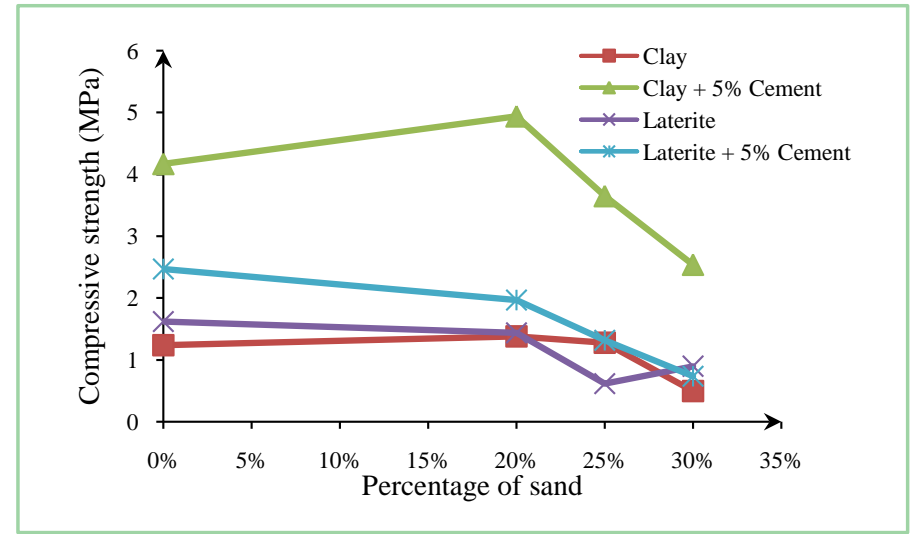

Figure 6. Compressive strengths of bricks, stabilized with $5 \%$ cement and unstabilized, clay and laterite.

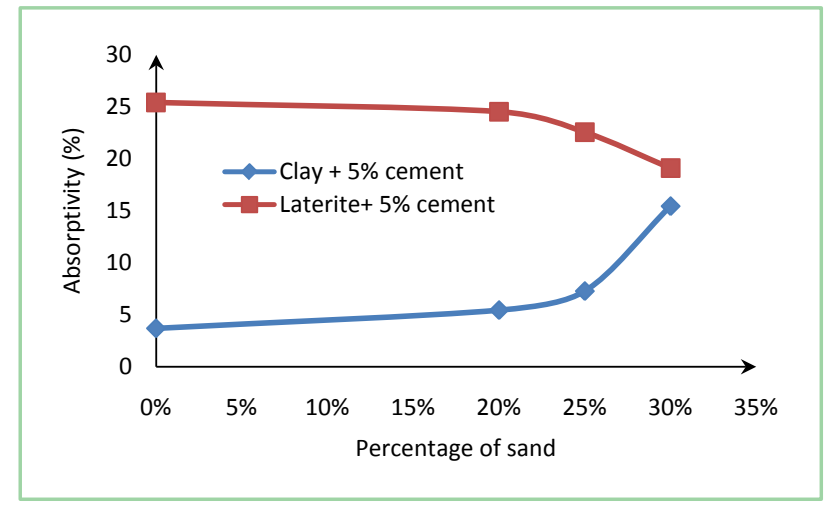

Figure 7. Absorbency of bricks stabilized with $5 \%$ cement, clay and laterite.

Table 8. Absorbency of clay and laterite bricks as a function of the percentage of sand.

\begin{tabular}{ccccc}
\hline Percentage of sand & $0 \%$ & $20 \%$ & $25 \%$ & $30 \%$ \\
\hline Clay & 3.70 & 5.45 & 7.28 & 15.45 \\
Laterite & 25.42 & 24.54 & 22.56 & 19.11
\end{tabular}

It should be noted that the addition of sand in the laterite decreases the porosity and unlike clay where the addition of sand promotes an increase in the spaces between the grains. In summary, the absorbency of clay is acceptable up to $25 \%$ sand because it is less than $15 \%$ maximum value set by the standard. [14] [15]. However, the absorbency of laterite bricks is higher than the maximum value set by the standard.

\section{Conclusion}

This study focuses on the characterization of compressed earth blocks. The bricks studied were made with clay and laterite and sand. The percentages of sand vary between $20 \%$ and $30 \%$ in steps of $5 \%$. Bricks stabilized with $5 \%$ class II cement are also produced from the same mixtures. 
The compressive strength of all unstabilized bricks is low. The resistance values vary between 0.5 to $1.24 \mathrm{MPa}$ and 0.90 to $1.62 \mathrm{MPa}$ respectively for clay and for laterite. For bricks stabilized with 5\% cement, compressive strengths are acceptable (greater than $2 \mathrm{MPa}$ ) for all clay bricks and for laterite bricks with $0 \%$ sand added.

The physical characterization of the bricks shows that the absorbency of clay is less than $15 \%$ and is acceptable up to $25 \%$ of sand. However, the absorbency of laterite bricks is higher than the maximum value set by the standard. To overcome this problem, the use of coatings on the exposed faces is recommended.

We recommend clay bricks with $20 \%$ sand and stabilized with $5 \%$ cement because they have optimal physico-mechanical properties.

In perspective, a thermal and acoustic characterization of the bricks will be made to assess the variation of the parameters according to the different formulations.

\section{Conflicts of Interest}

The authors declare no conflicts of interest regarding the publication of this paper.

\section{References}

[1] Holtz, R.D. and Kovacs, W.D. (1991) Introduction à la géotechnique. Presses Inter Polytechnique, 1991-1808.

[2] Hadidane, H., Oucief, H. and Merzoud, M. (2019). Comportement mécanique des couches d'assises modifiées par des débris de démolition. Academic Journal of Civil Engineering, 36, 529-533.

[3] Dupain, R., Lanchon, R. and Saint-Arroman, J.C. (2004) Granulats, sols, ciments et bétons: Caractérisation des matériaux de génie civil par les essais de laboratoire, Collection A. Capiliez, Boston, 28-29.

[4] Ayadat, T. and Belouahri, B. (1996) Influence du coefficient d'uniformité sur l'amplitude et le taux de l'affaissement des sols. Revue Française de Géotechnique, 76, 25-34. https://doi.org/10.1051/geotech/1996076025

[5] Ayadat, T. and Ouali, S. (1999) Identification des sols affaissables basée sur les limites d'Atterberg. Article No. 86, 53-56. https://www.geotechnique-journal.org/ https://doi.org/10.1051/geotech/1999086053

[6] Abbeche, K., Hammoud, F. and Ayadat, T. (2007) Influence of Relative Density and Clay Fraction on Soils Collapse. In: Dans Schanz, T., Ed., Experimental Unsatured Soil Mechanics, Springer, Berlin, Heidelberg, 3-9. https://doi.org/10.1007/3-540-69873-6_1

[7] Magnan, J.P. and Youssefian, G. (1989) Essai au bleu de méthylène. Essai au bleu de méthylène et classification géotechnique des sols. Bulletin de liaison des ponts et chausses, 93-104.

[8] Assande, A.A. (2007) Valorisation des latérites de Cote d'Ivoire: Fabrication des briquettes de parement à base de latérite stabilisée à froid à l'aide d'un liant hydraulique. le ciment portland. Université de Cocody.

[9] Amriou, A., Messaoudene, I., Bencheikh, M., Zaidi, B. and Messaadi, S. (2019) Eva- 
luation de l'influence du pourcentage de sable et du ciment sur la résistance à la compression du BTC. Rencontres Nationales de Génie Civil et d'Hydraulique. Skikda, les 13 et 14 novembre 2019, 8 .

[10] Boffoue, M.O., Kouadio, K.C., Kouakou, C.H.,. Assande, A.A., Dauscher,A., Lenoir, B. and Emeruwa, E. (2015) Influence de la teneur en ciment sur les propriétés thermomécaniques des blocs d'argile comprimée et stabilisée. Afrique Science, 11, 35-43.

[11] Aalil, I., Beck, K., Brunetaud, X., Cherkaou, K. and Al-Mukhtar, M. (2017) Estimation de la porosité et de l'absorption d'eau des pierres à l'aide des essais non destructifs : Cas de la calcarenite de Volubilis. Academic Journal of Civil Engineering, 35, 125-128.

[12] Guillaud, H., Joffroy, T. and Odul, P. (1995) Blocs de Terre comprimée: manuel de conception et de construction. Gesellschaft für Technische Zusammenarbeit (GTZ), Eschborn, 151.

[13] Phung, T.A. (2018) Formulation et caractérisation d'un composite terre-fibres végétales: La bauge. Thèse de doctorat, Université de Caen Normandie, Caen, 179.

[14] Ntom Nkotto, L.I., Dounbissi Kamgang, G., Sandjong Kanda, J., Suilabayu Loweh, S., Tiewa, J. and Likiby, B. (2020) Caractérisation des blocs produits par addition des fibres de coco et des matériaux de construction à base de latérite-ciment. Afrique Science, 17, 170-184.

[15] Balayssac, J.P., Detriche, C.H. and Grandet, J. (1993) Intérêt de l'essai d'absorption d'eau pour la caractérisation du béton d'enrobage. Materials and Structures, 26, 226. https://doi.org/10.1007/BF02472615 